\title{
Mediastinal Neurofibroma
}

National Cancer Institute

\section{Source}

National Cancer Institute. Mediastinal Neurofibroma. NCI Thesaurus. Code C6631.

A neurofibroma that arises from the posterior mediastinum. Excision is usually curative. 